\title{
Response of Iron and Zinc on Yield, Quality and Soil Nutrient Dynamics of Pearl Millet on Vertisol
}

\author{
S. L. Waikar ${ }^{1}$, S. M. Todmal ${ }^{2} *$ and V. S. Shete ${ }^{1}$ \\ ${ }^{1}$ Department of Soil Science and Agril. Chemistry, College of Agriculture, \\ Parbhani, M.S., India \\ ${ }^{2}$ Agricultural Research Station, ARS, K. Digraj, Sangli, M.S., India \\ *Corresponding author
}

\begin{tabular}{l} 
Ke y w o r d s \\
$\begin{array}{l}\text { Iron, zinc and pearl } \\
\text { millet }\end{array}$ \\
\hline Article Info \\
$\begin{array}{l}\text { Accepted: } \\
12 \text { March } 2021 \\
\text { Available Online: } \\
\text { 10 April } 2021\end{array}$ \\
\hline
\end{tabular}

\section{A B S T R A C T}

The field experiment was conducted to study the "Response of iron and zinc on yield, quality and soil nutrient dynamics of pearl millet on vertisol" was carried out at experimental farm, Department of Soil Science and Agricultural Chemistry, College of Agriculture, Parbhani during kharif 2019. The field experiment was laid out in Randomized Block Design with three replications and eight treatment combinations. The treatments consist of absolute Control, RDF (60:30:30 N: $\left.\mathrm{P}_{2} \mathrm{O}_{5}: \mathrm{K}_{2} \mathrm{O} \mathrm{kg} \mathrm{ha}^{-1}\right), \mathrm{RDF}+\mathrm{FeSO}_{4}$ $25 \mathrm{~kg} \mathrm{ha}^{-1}, \mathrm{RDF}+\mathrm{ZnSO}_{4} 25 \mathrm{~kg} \mathrm{ha}^{-1}, \mathrm{RDF}+\mathrm{FeSO}_{4} 25 \mathrm{~kg} \mathrm{ha}^{-1}+\mathrm{ZnSO}_{4} 25 \mathrm{Kg} \mathrm{ha}^{-1}, \mathrm{RDF}+$ foliar spray of $\mathrm{FeSO}_{4} @ 0.5 \%$ at $30 \mathrm{DAS} \& 45 \mathrm{DAS}, \mathrm{RDF}+$ foliar spray of $\mathrm{ZnSO}_{4} @ 0.5$ $\%$ at 30 DAS and 45 DAS and RDF + foliar spray of $\mathrm{FeSO}_{4}$ and $\mathrm{ZnSO}_{4} @ 0.5 \%$ at 30 DAS \& 45 DAS. Significantly higher grain and stover yield was produced with RDF + soil application of $25 \mathrm{~kg} \mathrm{ha}^{-1} \mathrm{FeSO}_{4}+25 \mathrm{~kg} \mathrm{ha}^{-1} \mathrm{ZnSO}_{4}$ and it was followed by the treatment $\mathrm{RDF}+$ foliar spray of $\mathrm{ZnSO}_{4}$ and $\mathrm{FeSO}_{4} @ 0.5 \%$ each at $30 \& 45 \mathrm{DAS}$. The uptake of nutrient was significantly influenced by different soil and foliar application treatments of $\mathrm{Fe}$ and $\mathrm{Zn}$. The maximum N, P and $\mathrm{K}$ uptake by pearl millet grain and stover was noticed in treatment consisting of RDF+ $25 \mathrm{~kg} \mathrm{ha}^{-1} \mathrm{FeSO}_{4}+25 \mathrm{~kg} \mathrm{ha}^{-1} \mathrm{ZnSO}_{4}$ followed by the $\mathrm{RDF}+$ foliar spray of $\mathrm{ZnSO}_{4}$ and $\mathrm{FeSO}_{4} @ 0.5 \%$ each at $30 \& 45$ DAS. Similarly, significantly highest $\mathrm{Fe}$ and $\mathrm{Zn}$ uptake by grain and stover was observed with $\mathrm{RDF}+25 \mathrm{~kg}$ $\mathrm{ha}^{-1} \mathrm{FeSO}_{4}+25 \mathrm{~kg} \mathrm{ha}{ }^{-1} \mathrm{ZnSO}_{4}$. The soil application of $\mathrm{Fe}$ and $\mathrm{Zn}$ to pearl millet significantly contributed in improving soil fertility and there by crop yield. The organic carbon content was highest in treatment $\mathrm{RDF}+\mathrm{FeSO}_{4} 25 \mathrm{~kg} \mathrm{ha}^{-1}+\mathrm{ZnSO}_{4} 25 \mathrm{~kg} \mathrm{ha}{ }^{-1}$, available nitrogen was highest in treatment $\mathrm{RDF}+$ foliar spray of $\mathrm{ZnSO}_{4} @ 0.5 \%$ at 30 DAS \& 45 DAS, available phosphorus was highest in treatment RDF + foliar spray of $\mathrm{FeSO}_{4} @ 0.5 \%$ at 30 DAS \& 45 DAS, available potassium was highest in treatment RDF and sulphur was observed highest with $\mathrm{RDF}+25 \mathrm{~kg} \mathrm{ha}^{-1} \mathrm{FeSO}_{4}+25 \mathrm{~kg} \mathrm{ha} \mathrm{ZnSO}_{4}$, Combined foliar application of $\mathrm{RDF}+0.5 \%$ chelated $\mathrm{Fe}$ and $\mathrm{Zn}$ at tillering and panicle initiation stages also significantly improved the nutrient availability. The maximum available $\mathrm{Fe}$ was noticed under $\mathrm{RDF}+25 \mathrm{~kg} \mathrm{ha}^{-1} \mathrm{FeSO}_{4}+25 \mathrm{~kg} \mathrm{ha}^{-1} \mathrm{ZnSO}_{4}$ and the maximum availability of $\mathrm{Zn}$ was observed with $\mathrm{RDF}+25 \mathrm{~kg} \mathrm{ha}^{-1} \mathrm{FeSO}_{4}+25 \mathrm{~kg} \mathrm{ha}^{-1}$ $\mathrm{ZnSO}_{4}$. Soil and foliar application of $\mathrm{Fe}$ and $\mathrm{Zn}$ along with $\mathrm{RDF}$ found beneficial in improving the soil nutrient status, nutrient uptake and there by pearl millet yield. 


\section{Introduction}

Pearl millet (Pennisetum glaucum) is most commonly grown type millet. It is commonly known as bajara. It is being grown in Indian continent since prehistoric times. Pearl millet is well adapted to growing area characterized by drought, low productivity and high temperature. India is largest producer of pearl millet with an area of 6.93 million ha with production of 8.61 million tones with productivity of $1243 \mathrm{~kg} \mathrm{ha}^{-1}$ during 2018 2019 (Anonymous, 2019).

In Maharashtra, this crop is grown on 7.01 lakh ha of land with 3.32 lakh tones of grain production having productivity of $412 \mathrm{~kg} \mathrm{ha}^{-1}$ in 2018-2019. Iron and Zinc deficiency in Indian soils and response to their application to various crops have been reported by (Tiwari and Dwivedi, 1993). Nutrients play a vital role in biosynthesis of protein and amino acids. Use of manures and IPNS reduced the micronutrient fertilizer necessities of crops and enhances remaining effect. The problems of micronutrients after the green revolution are relatively different.

Continuous use of high analysis fertilizer under intensify crop and carelessness of organic manures manifested the amount of common micronutrients deficiencies of $\mathrm{Fe}$ and $\mathrm{Zn}$ in light texture soils of India (Singh, 2006). The function of micronutrients in various physical and biochemical processes in plant is well known, which enables quick change in physiology of plant within one season to realize popular results.

Looking to general deficiency of Iron and Zinc and its response to pearl millet crop in terms of foliar as well as soil application to this crop, the present field research was undertaken to study the response of hybrid pearl millet to soil and foliar application of Iron and Zinc on Vertisol.

\section{Materials and Methods}

A field experiment was conducted during kharif -2019 to study the response of iron and zinc on growth, yield and soil nutrient dynamics of pearl millet on vertisol at Research Farm of Soil Science and Agricultural Chemistry, Vasantrao Naik Marathwada Krishi Vidyapeeth, Parbhani, Maharashtra (India). The experiment was laid out in randomized block design (RBD) with three replications and eight treatments. The treatment comprised of absolute control $\left(\mathrm{T}_{1}\right)$, $\operatorname{RDF}\left(60: 30: 30 \quad \mathrm{~N}: \mathrm{P}_{2} \mathrm{O}_{5}: \mathrm{K}_{2} \mathrm{O} \quad \mathrm{kg} \mathrm{ha}^{-1}\right)\left(\mathrm{T}_{2}\right)$, $\mathrm{RDF}+\mathrm{FeSO}_{4} 25 \mathrm{~kg} \mathrm{ha}^{-1}\left(\mathrm{~T}_{3}\right), \mathrm{RDF}+\mathrm{ZnSO}_{4}$ $25 \mathrm{~kg} \mathrm{ha}^{-1}\left(\mathrm{~T}_{4}\right), \mathrm{RDF}+\mathrm{FeSO}_{4} 25 \mathrm{~kg} \mathrm{ha}^{-1}+$ $\mathrm{ZnSO}_{4} 25 \mathrm{Kg} \mathrm{ha}^{-1}\left(\mathrm{~T}_{5}\right), \mathrm{RDF}+$ foliar spray of $\mathrm{FeSO}_{4} @ 0.5 \%$ at $30 \mathrm{DAS} \& 45 \mathrm{DAS}\left(\mathrm{T}_{6}\right)$, $\mathrm{RDF}+$ foliar spray of $\mathrm{ZnSO}_{4} @ 0.5 \%$ at 30 DAS and 45 DAS $\left(\mathrm{T}_{7}\right)$ and RDF + foliar spray of $\mathrm{FeSO}_{4}$ and $\mathrm{ZnSO}_{4} @ 0.5 \%$ at $30 \mathrm{DAS} \&$ 45 DAS $\left(\mathrm{T}_{8}\right)$. The Pearl millet (Bajara) $C v$. AHB1200 was taken as test crop. The chemical fertilizers were applied as per treatments. The plant observations were recorded during growth of the crop and at the time of harvest of the crop. The surface soil samples $(0-15 \mathrm{~cm})$ were collected initial and harvest of crops and analysed for chemical properties of soil by adopting standard procedures.

\section{Results and Discussion}

The data in respect of grain and stover yield of pearl millet as influenced by $\mathrm{Fe}$ and $\mathrm{Zn}$ application is presented in Table 1 . There was significant increase in yield due to the different treatments. Highest grain yield $\left(28.89 \mathrm{q} \mathrm{ha}^{-1}\right)$ and stover yield $\left(61.31 \mathrm{q} \mathrm{ha}^{-1}\right)$ yield of pearl millet was recorded in the treatment receiving $\mathrm{RDF}+$ soil application of $25 \mathrm{~kg} \mathrm{ha}^{-1} \mathrm{FeSO}_{4}+25 \mathrm{~kg} \mathrm{ha}^{-1} \mathrm{ZnSO}_{4}$ (T5) and it was followed by grain yield (27.48 $\left.\mathrm{q} \mathrm{ha}^{-1}\right)$ and stover yield $\left(58.28 \mathrm{q} \mathrm{ha}^{-1}\right) \mathrm{RDF}+$ foliar spray of $\mathrm{ZnSO} 4$ and FeSO4 @ $0.5 \%$ each at 
$30 \& 45$ DAS (T8), respectively. Close examination of the results noticed that the treatment T5 was found statistically at par with treatments T8, T3 and T4. Increase in wheat yield due to foliar application of micronutrients was observed by Narimani et al., (2010). While, NPK along with Fe and Zn increased the cotton yield was reported by Sangh et al., (2012); and pearl millet yield was noted by Prasad et al., (2014). This yield enhance in this study due to improvement in yield attributes because of balanced supply of nutrients.

The data on protein content in pearl millet grain are presented in table 1 . The significantly highest protein content in grain $(15.79 \%)$ was observed in treatment $\mathrm{T} 5$ $\left(\mathrm{RDF}+25 \mathrm{~kg} \mathrm{ha}^{-1} \mathrm{FeSO} 4+25 \mathrm{~kg} \mathrm{ha}^{-1} \mathrm{ZnSO} 4\right)$ which were at par with treatment T4 (14.72 \%) (RDF $\left.+25 \mathrm{~kg} \mathrm{ha}^{-1} \mathrm{ZnSO} 4\right)$ and with treatment T8 $(14.09 \%)(\mathrm{RDF}+$ foliar spray of ZnSO4 and FeSO4@0.5\% each at 30 \& 45DAS). Palta et al., (2005) reported that the seed protein content increased with nitrogen availability in chickpea. Similarly, Kinra et al., (1967) also resulted that foliar versus soil application of nitrogen to pearl millet was not much difference in protein content and carbohydrates content.

The data regarding 1000 grain weight after harvesting of pearl millet is given in Table 1 . The 1000 grain weight $(\mathrm{g})$ of pearl millet was recorded at harvest. The results indicated the significant increase in grain weight due to the application of micronutrients as compared to RDF and control. The maximum grain weight $(18.50 \mathrm{~g})$ was recorded with $\mathrm{RDF}+$ soil application of $25 \mathrm{~kg} \mathrm{FeSO}_{4}+25 \mathrm{~kg} \mathrm{ZnSO}$ treatment $\left(\mathrm{T}_{5}\right)$, followed by $\mathrm{RDF}+$ soil application of $25 \mathrm{~kg} \mathrm{FeSO}_{4}\left(\mathrm{~T}_{3}\right)$ having 17.62 g grain weight. The treatment $\left(\mathrm{T}_{4}\right) \mathrm{RDF}+$ Soil application of $\mathrm{ZnSO}_{4}$ also noticed increase in the grain weight $(17.09 \mathrm{~g})$. With foliar application, the treatment receiving RDF + foliar application of $0.5 \%$ chelated $\mathrm{Fe}+0.5 \%$ chelated Zn @ two stages $\left(\mathrm{T}_{8}\right)$ recorded significantly higher grain weight of $16.59 \mathrm{~g}$. The increase in grain weight was due to the application of RDF + soil application of $25 \mathrm{~kg}$ FeSO4+ $25 \mathrm{~kg} \mathrm{ZnSO} 4$ which increased the uptake of nutrients by plants was previously noticed by Ravi and Channal (2010). Similar effect of soil application of $\mathrm{Zn}$ on growth and yield of maize was noticed by Asha et al., (2012) and on pearl millet by Prasad et al., (2014).

Total chlorophyll content of Pearl millet as influenced by application of iron and zinc are presented in table 1 . The significantly highest total chlorophyll content $\left(11.72 \mathrm{mg} 100 \mathrm{~g}^{-1}\right)$ was observed in treatment $\mathrm{RDF}+$ soil application of $25 \mathrm{~kg} \mathrm{ha}^{-1} \mathrm{FeSO}_{4}+25 \mathrm{~kg} \mathrm{ha}^{-1}$ $\mathrm{ZnSO}_{4}\left(\mathrm{~T}_{5}\right)$ which was followed by total chlorophyll content $\left(11.00 \quad \mathrm{mg} \quad 100 \quad \mathrm{~g}^{-1}\right)$ observed in treatment RDF + foliar spray of $\mathrm{FeSO}_{4}$ and $\mathrm{ZnSO}_{4} @ 0.5 \%$ at $30 \mathrm{DAS} \& 45$ DAS $\left(\mathrm{T}_{8}\right)$. The results are in conformity with (Kinra et al., 1967).

Total data pertaining to total nutrient uptake by Pearl millet as influenced by application of iron and zinc are presented in table 2. The total nitrogen varied from 39.14 to $88.48 \mathrm{~kg}$ $\mathrm{ha}^{-1}$ with mean value $63.81 \mathrm{~kg} \mathrm{ha}{ }^{-1}$. The significantly highest total nitrogen uptake $\left(88.48 \mathrm{~kg} \mathrm{ha}^{-1}\right)$ was recorded in the treatment with RDF + $25 \mathrm{~kg} \mathrm{ha}^{-1} \mathrm{FeSO}_{4}+25 \mathrm{~kg} \mathrm{ha}^{-1}$ $\mathrm{ZnSO}_{4}\left(\mathrm{~T}_{5}\right)$ found superior over rest of the treatments. Increase in uptake of nutrients by application of $\mathrm{Zn}$ and $\mathrm{Fe}$ to mustard crop previously reported by Kumar et al., (2014) and in soybean crop by Goli et al., (2015).

The total phosphorus uptake was varied from 13.43 to $43.34 \mathrm{~kg} \mathrm{ha}^{-1}$ with mean value 28.38 $\mathrm{kg} \mathrm{ha}{ }^{-1}$, respectively. The highest total phosphorus uptake $\left(43.34 \mathrm{~kg} \mathrm{ha}^{-1}\right)$ was found in the treatment RDF $+25 \mathrm{~kg} \mathrm{ha}^{-1} \mathrm{FeSO} 4+25$ $\mathrm{kg} \mathrm{ha}^{-1} \mathrm{ZnSO} 4$ (T5) and it was followed by the 
total phosphorus uptake (36.58 $\left.\mathrm{kg} \mathrm{ha}^{-1}\right)$ recorded in the RDF +25 kg ha-1 FeSO4 (T3). Increase in uptake of phosphorus uptake by application of $\mathrm{Zn}$ and $\mathrm{Fe}$ in soybean was also reported earlier by Goli et al., (2015).

Among all the treatments treatment RDF +25 $\mathrm{kg} \mathrm{ha}{ }^{-1} \mathrm{FeSO} 4+25 \mathrm{~kg} \mathrm{ha}^{-1} \mathrm{ZnSO} 4$ (T5) recorded significantly highest potassium uptake $\left(213.65 \mathrm{~kg} \mathrm{ha}^{-1}\right)$ and it was followed by the potassium uptake $\left(197.31 \mathrm{~kg} \mathrm{ha} \mathrm{ha}^{-1}\right)$ recorded in the treatment $\mathrm{RDF}+$ foliar spray of $\mathrm{ZnSO} 4$ and FeSO4 @ $0.5 \%$ each at 30 \& 45 DAS (T8). The results were in conformity with Kumar et al., (2014).

The significantly highest total sulphur uptake (7.00 $\mathrm{kg} \mathrm{ha}^{-1}$ ) was found in the treatment RDF + $25 \mathrm{~kg} \mathrm{ha}^{-1} \mathrm{FeSO} 4+25 \mathrm{~kg} \mathrm{ha}^{-1} \mathrm{ZnSO} 4$ (T5) which was followed by the total sulphur uptake $\left(5.96 \mathrm{~kg} \mathrm{ha}^{-1}\right)$ recorded in $\mathrm{RDF}+$ foliar spray of $\mathrm{ZnSO} 4$ and FeSO4 @ $0.5 \%$ each at $30 \& 45$ DAS (T8). The positive effect of S, $\mathrm{Zn}$ and Fe application on micronutrient uptake by safflower was noticed by Ravi and Channel (2010).

The data presented in Table 2 showed that the total uptake of micronutrients in pearl millet was influenced by different treatments of iron and zinc. The treatment RDF+ $25 \mathrm{~kg} \mathrm{ha}^{-1}$ $\mathrm{FeSO}_{4}+25 \mathrm{~kg} \mathrm{ha}^{-1} \mathrm{ZnSO} 4\left(\mathrm{~T}_{5}\right)$ recorded the significantly highest iron uptake $\left(785.65 \mathrm{~g} \mathrm{ha}^{-}\right.$ $\left.{ }^{1}\right)$ and it was followed by iron uptake (669.61 $\mathrm{g} \mathrm{ha}^{-1}$ ) recorded in the treatment $\mathrm{RDF}+25 \mathrm{~kg}$ $\mathrm{ha}^{-1} \mathrm{FeSO}_{4}\left(\mathrm{~T}_{3}\right)$. This trend may be due to the increase in growth and yield component which ultimately enhanced the nutrient uptake. Similar effect of increase in uptake was also pointed out by El-Fouly et al., (2012).

The zinc uptake was significantly influenced by different fertilizer treatments. The highest zinc uptake (351.94 $\left.\mathrm{g} \mathrm{ha}^{-1}\right)$ was the treatment $\mathrm{RDF}+25 \mathrm{~kg} \mathrm{ha}^{-1} \mathrm{FeSO} 4+25 \mathrm{~kg} \mathrm{ha}^{-1} \mathrm{ZnSO} 4$
(T5) found superior over rest of the treatments. However, the lowest zinc uptake (161.44 $\mathrm{g} \mathrm{ha}^{-1}$ ) was observed in absolute control (T1). The uptake of zinc is more in treatment (T5) due to higher concentration of zinc in seed and stover and their yield is also higher in similar treatment. The results are in conformity with Ravi and Channel (2010).

The data pertaining to soil reaction and salt content is presented in table No 3. The $\mathrm{pH}$ and EC shows non-significant results and only small fluctuation seen due to the administration of treatments. The range of $\mathrm{pH}$ and EC was 8.03 to 7.78 and 0.40 to $0.31 \mathrm{dS}$ $\mathrm{m}^{-1}$, respectively. The average soil $\mathrm{pH}$ and electrical conductivity was 7.90 and $0.35 \mathrm{dS}$ $\mathrm{m}^{-1}$, respectively. There were no significant changes observed regarding soil $\mathrm{pH}$ and electrical conductivity at harvest stage.

The soil organic carbon content at harvest of pearl millet was ranged between 5.47 to $5.57 \mathrm{~g}$ $\mathrm{kg}^{-1}$. The highest content of organic carbon (5.57 $\left.\mathrm{g} \mathrm{kg}^{-1}\right)$ was recorded with RDF + soil application of $25 \mathrm{~kg} \mathrm{ha}^{-1} \mathrm{FeSO}_{4}+25 \mathrm{~kg} \mathrm{ha}^{-1}$ $\mathrm{ZnSO}_{4}\left(\mathrm{~T}_{5}\right)$ and it was followed by RDF + soil application of $25 \mathrm{~kg} \mathrm{ha}^{-1} \mathrm{FeSO}_{4}\left(\mathrm{~T}_{3}\right)$ i.e. $5.56 \mathrm{~g}$ $\mathrm{kg}^{-1}$. Among the foliar application treatments, the higher organic carbon $\left(5.55 \mathrm{~g} \mathrm{~kg}^{-1}\right)$ was recorded in $\mathrm{RDF}+$ foliar application of $0.5 \%$ chelated $\mathrm{Fe}+0.5 \%$ chelated $\mathrm{Zn}$ at two crop stages $\left(\mathrm{T}_{8}\right)$. Individual foliar spray of $0.5 \% \mathrm{Fe}$ and $\mathrm{Zn}$ along with RDF also increased organic carbon over RDF alone and control. Similar results were found by Durgude et al., (2014) with soil and foliar application of zinc and iron in cotton experiment.

The data regarding available nitrogen of pearl millet is given in Table 4 . The available nitrogen content of pearl millet indicated the significant increase in available nitrogen content due to different treatments combination over control. 
Table.1 Effect of different treatments of iron and zinc application on yield and quality of pearl millet

\begin{tabular}{|c|c|c|c|c|c|c|}
\hline \multirow{2}{*}{$\begin{array}{l}\text { Tr. } \\
\text { No. }\end{array}$} & \multirow[t]{2}{*}{ Treatment } & \multicolumn{2}{|c|}{ Yield $\left(q\right.$ ha $\left.^{-1}\right)$} & \multirow{2}{*}{$\begin{array}{c}1000 \\
\text { grain } \\
\text { weight } \\
\text { (g) }\end{array}$} & \multirow{2}{*}{$\begin{array}{c}\text { Protein } \\
\text { content } \\
(\%)\end{array}$} & \multirow{2}{*}{$\begin{array}{c}\text { Total } \\
\text { chlorophyll } \\
\text { content } \\
\left(\mathrm{mg} 100 \mathrm{~g}^{-1}\right)\end{array}$} \\
\hline & & Grain & Yield & & & \\
\hline $\mathbf{T}_{1}$ & Absolute control & 15.44 & 34.66 & 15.09 & 10.85 & 7.02 \\
\hline $\mathbf{T}_{2}$ & $\mathrm{RDF}\left(60: 30: 30 \mathrm{~N}: \mathrm{P}_{2} \mathrm{O}_{5}: \mathrm{K}_{2} \mathrm{O} \mathrm{kg} \mathrm{ha}^{-1}\right.$ & 25.18 & 54.55 & 15.85 & 12.96 & 8.34 \\
\hline $\mathbf{T}_{\mathbf{3}}$ & $\mathrm{RDF}+25 \mathrm{~kg} \mathrm{ha}^{-1} \mathrm{FeSO}_{4}$ & 26.78 & 57.57 & 17.62 & 13.39 & 10.46 \\
\hline $\mathbf{T}_{4}$ & $\mathrm{RDF}+25 \mathrm{~kg} \mathrm{ha}^{-1} \mathrm{ZnSO}_{4}$ & 26.41 & 56.17 & 17.09 & 14.72 & 8.62 \\
\hline $\mathbf{T}_{5}$ & $\begin{array}{c}\mathrm{RDF}+25 \mathrm{~kg} \mathrm{ha}^{-1} \mathrm{FeSO}_{4}+25 \mathrm{~kg} \mathrm{ha}^{-1} \\
\mathrm{ZnSO}_{4}\end{array}$ & 28.89 & 61.31 & 18.50 & 15.89 & 11.72 \\
\hline $\mathbf{T}_{6}$ & $\begin{array}{c}\mathrm{RDF}+\text { foliar spray of } \mathrm{FeSO}_{4} @ 0.5 \\
\% \text { at } 30 \& 45 \mathrm{DAS}\end{array}$ & 25.27 & 53.42 & 16.36 & 12.87 & 9.31 \\
\hline $\mathbf{T}_{7}$ & $\begin{array}{c}\mathrm{RDF}+\text { foliar spray of } \mathrm{ZnSO}_{4} @ 0.5 \\
\% \text { at } 30 \& 45 \mathrm{DAS}\end{array}$ & 25.61 & 53.65 & 16.35 & 12.87 & 8.71 \\
\hline $\mathbf{T}_{8}$ & $\begin{array}{c}\mathrm{RDF}+\text { foliar spray of } \mathrm{ZnSO}_{4} \text { and } \\
\mathrm{FeSO}_{4} @ 0.5 \% \text { each at } 30 \& 45 \mathrm{DAS}\end{array}$ & 27.48 & 58.28 & 16.59 & 14.09 & 11.00 \\
\hline & Mean & 25.13 & 53.70 & 16.68 & 13.44 & 9.40 \\
\hline & S.E. \pm & 1.05 & 2.19 & 0.38 & 0.73 & 0.57 \\
\hline & C.D.@ 5\% & 3.16 & 6.63 & 1.15 & 2.22 & 1.74 \\
\hline
\end{tabular}

Table.2 Effect of different treatments of iron and zinc application on nutrient uptake in pearl millet

\begin{tabular}{|c|c|c|c|c|c|c|c|}
\hline \multirow[t]{2}{*}{$\begin{array}{l}\text { Tr. } \\
\text { No. }\end{array}$} & \multirow[t]{2}{*}{ Treatment } & \multicolumn{4}{|c|}{$\begin{array}{l}\text { Nutrient uptake } \\
\left(\mathrm{kg} \mathrm{ha}^{-1}\right)\end{array}$} & \multicolumn{2}{|c|}{$\begin{array}{l}\text { Micronutrient } \\
\text { uptake }\left(\mathrm{g} \mathrm{ha}^{-1}\right)\end{array}$} \\
\hline & & $\mathbf{N}$ & $\mathbf{P}$ & $\mathbf{K}$ & $\mathbf{S}$ & $\mathrm{Fe}$ & $\mathbf{Z n}$ \\
\hline $\mathbf{T}_{1}$ & Absolute control & 39.14 & 13.43 & 104.30 & 2.92 & 286.66 & 161.44 \\
\hline $\mathbf{T}_{2}$ & RDF (60:30:30 N: $\mathrm{P}_{2} \mathrm{O}_{5}: \mathrm{K}_{2} \mathrm{O} \mathrm{kg} \mathrm{ha}{ }^{-1}$ & 67.40 & 30.93 & 173.72 & 4.47 & 566.33 & 289.66 \\
\hline $\mathbf{T}_{\mathbf{3}}$ & $\mathrm{RDF}+25 \mathrm{~kg} \mathrm{ha}^{-1} \mathrm{FeSO}_{4}$ & 76.65 & 36.58 & 186.74 & 5.84 & 669.61 & 309.49 \\
\hline $\mathbf{T}_{4}$ & $\mathrm{RDF}+25 \mathrm{~kg} \mathrm{ha}^{-1} \mathrm{ZnSO}_{4}$ & 77.82 & 34.12 & 180.32 & 5.88 & 588.54 & 347.12 \\
\hline $\mathbf{T}_{5}$ & $\begin{array}{c}\mathrm{RDF}+25 \mathrm{~kg} \mathrm{ha}^{-1} \mathrm{FeSO}_{4}+25 \mathrm{~kg} \mathrm{ha}^{-1} \\
\mathrm{ZnSO}_{4}\end{array}$ & 88.48 & 43.34 & 213.65 & 7.00 & 785.65 & 443.85 \\
\hline $\mathbf{T}_{6}$ & $\begin{array}{l}\mathrm{RDF}+\text { foliar spray of } \mathrm{FeSO}_{4} @ 0.5 \% \text { at } \\
30 \& 45 \mathrm{DAS}\end{array}$ & 71.01 & 33.71 & 175.80 & 5.75 & 574.51 & 283.16 \\
\hline $\mathbf{T}_{7}$ & $\begin{array}{l}\mathrm{RDF}+\text { foliar spray of } \mathrm{ZnSO}_{4} @ 0.5 \% \text { at } \\
30 \& 45 \mathrm{DAS}\end{array}$ & 72.42 & 35.43 & 179.04 & 5.29 & 576.85 & 311.34 \\
\hline $\mathbf{T}_{8}$ & $\begin{array}{l}\mathrm{RDF}+\text { foliar spray of } \mathrm{ZnSO}_{4} \text { and } \mathrm{FeSO}_{4} \\
\text { @ } 0.5 \% \text { each at } 30 \& 45 \mathrm{DAS}\end{array}$ & 79.38 & 34.95 & 197.31 & 5.96 & 655.78 & 351.94 \\
\hline & Mean & 71.57 & 32.81 & 176.36 & 5.39 & 587.99 & 312.25 \\
\hline & S.E. \pm & 2.92 & 1.44 & 7.74 & 0.35 & 23.2 & 16.78 \\
\hline & C.D.@ 5\% & 8.83 & 4.37 & 23.39 & 1.07 & 70.06 & 50.91 \\
\hline
\end{tabular}


Table.3 Effect of different treatments of iron and zinc application on soil properties at harvest of pearl millet

\begin{tabular}{|c|c|c|c|c|}
\hline Tr. No. & Treatment & $\begin{array}{c}\text { pH } \\
(1: 2.5)\end{array}$ & $\begin{array}{c}\mathbf{E C} \\
\left(\mathbf{d S} \mathbf{~ m}^{-1}\right)\end{array}$ & $\underset{\left(\mathrm{g} \mathrm{kg}^{-1}\right)}{\mathbf{O C}}$ \\
\hline $\mathbf{T}_{1}$ & Absolute control & 7.85 & 0.31 & 5.47 \\
\hline $\mathbf{T}_{2}$ & $\mathrm{RDF}\left(60: 30: 30 \mathrm{~N}: \mathrm{P}_{2} \mathrm{O}_{5}: \mathrm{K}_{2} \mathrm{O} \mathrm{kg} \mathrm{ha}{ }^{-1}\right.$ & 8.01 & 0.34 & 5.53 \\
\hline $\mathbf{T}_{3}$ & $\mathrm{RDF}+25 \mathrm{~kg} \mathrm{ha}^{-1} \mathrm{FeSO}_{4}$ & 7.78 & 0.40 & 5.55 \\
\hline$T_{4}$ & $\mathrm{RDF}+25 \mathrm{~kg} \mathrm{ha}^{-1} \mathrm{ZnSO}_{4}$ & 7.90 & 0.35 & 5.54 \\
\hline $\mathbf{T}_{5}$ & $\mathrm{RDF}+25 \mathrm{~kg} \mathrm{ha}^{-1} \mathrm{FeSO}_{4}+25 \mathrm{~kg} \mathrm{ha}^{-1} \mathrm{ZnSO}_{4}$ & 7.91 & 0.32 & 5.57 \\
\hline $\mathbf{T}_{6}$ & $\begin{array}{c}\mathrm{RDF}+\text { foliar spray of } \mathrm{FeSO}_{4} @ 0.5 \% \text { at } 30 \& \\
45 \mathrm{DAS}\end{array}$ & 7.89 & 0.39 & 5.54 \\
\hline $\mathbf{T}_{7}$ & $\begin{array}{l}\mathrm{RDF}+\text { foliar spray of } \mathrm{ZnSO}_{4} @ 0.5 \% \text { at } 30 \& \\
45 \mathrm{DAS}\end{array}$ & 8.03 & 0.37 & 5.53 \\
\hline \multirow[t]{4}{*}{$\mathbf{T}_{8}$} & $\begin{array}{c}\mathrm{RDF}+\text { foliar spray of } \mathrm{ZnSO}_{4} \text { and } \mathrm{FeSO}_{4} @ 0.5 \\
\% \text { each at } 30 \& 45 \mathrm{DAS}\end{array}$ & 7.99 & 0.37 & 5.55 \\
\hline & Mean & 7.92 & 0.35 & 5.54 \\
\hline & S.E. \pm & 0.52 & 0.021 & 0.011 \\
\hline & C.D. @ 5\% & NS & NS & 0.034 \\
\hline
\end{tabular}

Table.4 Effect of different treatments of iron and zinc application on soil properties at harvest of pearl millet

\begin{tabular}{|c|c|c|c|c|c|c|c|}
\hline \multirow[t]{2}{*}{$\begin{array}{l}\text { Tr. } \\
\text { No. }\end{array}$} & \multirow[t]{2}{*}{ Treatment } & \multicolumn{4}{|c|}{ Available nutrients $\left(\mathrm{kg} \mathrm{ha}^{-1}\right)$} & \multicolumn{2}{|c|}{$\begin{array}{c}\text { DTPA } \\
\text { Micronutrient } \\
\left(\mathrm{mg} \mathrm{kg}^{-1}\right)\end{array}$} \\
\hline & & $\mathbf{N}$ & $\mathbf{P}$ & $\mathbf{K}$ & $\mathbf{S}$ & $\mathbf{F e}$ & Zn \\
\hline $\mathbf{T}_{1}$ & Absolute control & 148.33 & 13.14 & 553.00 & 33.21 & 3.914 & 0.614 \\
\hline $\mathbf{T}_{2}$ & $\begin{array}{c}\mathrm{RDF}\left(60: 30: 30 \mathrm{~N}: \mathrm{P}_{2} \mathrm{O}_{5}: \mathrm{K}_{2} \mathrm{O} \mathrm{kg}\right. \\
\mathrm{ha}^{-1}\end{array}$ & 167.00 & 17.66 & 586.67 & 37.44 & 4.802 & 0.621 \\
\hline $\mathbf{T}_{3}$ & $\mathrm{RDF}+25 \mathrm{~kg} \mathrm{ha}^{-1} \mathrm{FeSO}_{4}$ & 165.67 & 16.86 & 573.00 & 39.35 & 5.011 & 0.734 \\
\hline $\mathbf{T}_{4}$ & $\mathrm{RDF}+25 \mathrm{~kg} \mathrm{ha}^{-1} \mathrm{ZnSO}_{4}$ & 170.67 & 17.18 & 583.67 & 41.26 & 4.791 & 0.872 \\
\hline $\mathbf{T}_{5}$ & $\begin{array}{c}\mathrm{RDF}+25 \mathrm{~kg} \mathrm{ha}^{-1} \mathrm{FeSO}_{4}+25 \mathrm{~kg} \\
\mathrm{ha}^{-1} \mathrm{ZnSO}_{4}\end{array}$ & 168.33 & 16.59 & 572.67 & 43.16 & 5.233 & 1.015 \\
\hline $\mathbf{T}_{6}$ & $\begin{array}{c}\mathrm{RDF}+\text { foliar spray of } \mathrm{FeSO}_{4} @ \\
0.5 \% \text { at } 30 \& 45 \mathrm{DAS}\end{array}$ & 170.33 & 17.86 & 584.67 & 38.19 & 4.761 & 0.637 \\
\hline $\mathbf{T}_{7}$ & $\begin{array}{c}\mathrm{RDF}+\text { foliar spray of } \mathrm{ZnSO}_{4} @ \\
0.5 \% \text { at } 30 \& 45 \mathrm{DAS}\end{array}$ & 173.33 & 17.39 & 583.33 & 38.47 & 4.772 & 0.697 \\
\hline$T_{8}$ & $\begin{array}{c}\mathrm{RDF}+\text { foliar spray of } \mathrm{ZnSO}_{4} \text { and } \\
\mathrm{FeSO}_{4} @ 0.5 \% \text { each at } 30 \& 45 \\
\text { DAS }\end{array}$ & 168.67 & 16.82 & 568.33 & 36.23 & 4.781 & 0.647 \\
\hline & Mean & 166.54 & 16.69 & 575.67 & 38.41 & 4.758 & 0.730 \\
\hline & S.E. \pm & 4.48 & 0.57 & 5.96 & 1.69 & 0.14 & 0.039 \\
\hline & C.D.@ 5\% & 13.55 & 1.72 & 18 & 5.11 & 0.42 & 0.119 \\
\hline
\end{tabular}


Maximum available nitrogen (173.33 $\left.\mathrm{kg} \mathrm{ha}^{-1}\right)$ at harvest of pearl millet was recorded in the treatment receiving RDF + foliar spray of ZnSO4@0.5\% at 30 and $45 \mathrm{DAS}\left(\mathrm{T}_{5}\right)$ and it was followed by RDF + soil application of 25 $\mathrm{kg} \mathrm{ha} \mathrm{ZnSO}_{4}{ }^{-1}\left(\mathrm{~T}_{4}\right)$. The results are in conformity with Mahatma (2007).

The maximum available phosphorus content was at harvest of pearl millet was recorded with RDF + foliar spray of $\mathrm{FeSO}_{4} @ 0.5 \%$ at $30 \& \quad 45$ DAS $\left(\mathrm{T}_{6}\right)$ followed by soil application of RDF $\left(\mathrm{T}_{2}\right)$ and $\mathrm{RDF}+$ foliar spray of $\mathrm{ZnSO}_{4} @ 0.5 \%$ at $30 \& 45 \mathrm{DAS}\left(\mathrm{T}_{7}\right)$ i.e. $17.86,17.66$ and $17.39 \mathrm{~kg} \mathrm{ha}{ }^{-1}$, respectively. Reddy et al., (2007) observed that either soil application or seed treatment along with uniform dose of RDF to pigeon pea have shown significant change in soil $\mathrm{P}$ status.

The highest available potassium $(586.67 \mathrm{~kg}$ $\mathrm{ha}^{-1}$ ) was recorded in treatment receiving RDF $\left(\mathrm{T}_{2}\right)$ and it was followed by the available potassium $\left(584.67 \mathrm{~kg} \mathrm{ha}^{-1}\right)$ found in the treatment with application of $\mathrm{RDF}+$ foliar spray of $\mathrm{FeSO}_{4} @ 0.5 \%$ at 30 \& $45 \mathrm{DAS}\left(\mathrm{T}_{6}\right)$. These results were close conformity with Mahatma (2007).

The data regarding available sulphur at harvest of pearl millet is given in Table 4.The treatment RDF + soil application of $25 \mathrm{~kg} \mathrm{ha}^{-1}$ $\mathrm{FeSO}_{4}+25 \mathrm{~kg} \mathrm{ha}^{-1} \mathrm{ZnSO}_{4}\left(\mathrm{~T}_{5}\right)$ recorded the maximum available sulfur content $(43.16 \mathrm{mg}$ $\mathrm{kg}^{-1}$ ) followed by RDF + soil application of 25 $\mathrm{kg} \mathrm{ha}^{-1} \mathrm{ZnSO}_{4}\left(41.26 \mathrm{mg} \mathrm{kg}^{-1}\right)$. These results matched with the finding of Kanzariya et al., 2010 .

The data pertaining to the DTPA extractable iron presented in table 4 . The iron content in soil ranged between 39.14 to $5.233 \mathrm{mg} \mathrm{kg}^{-1}$ in different treatments. Although, it was bring the fact that soil application of Fe and $\mathrm{Zn}$ showed the higher values as compared to foliar application. The RDF $+25 \mathrm{~kg} \mathrm{ha}^{-1}$
$\mathrm{FeSO}_{4}+25 \mathrm{~kg} \mathrm{ha}^{-1} \mathrm{ZnSO}_{4}\left(\mathrm{~T}_{5}\right)$ recorded the maximum iron content $\left(5.233 \mathrm{mg} \mathrm{kg}^{-1}\right)$ followed by $\mathrm{RDF}+25 \mathrm{~kg} \mathrm{ha}{ }^{-1} \mathrm{FeSO}_{4}\left(\mathrm{~T}_{3}\right)$ $\left(5.011 \mathrm{mg} \mathrm{kg}^{-1}\right)$. While, RDF + foliar spray of $\mathrm{ZnSO}_{4}$ and $\mathrm{FeSO}_{4} @ 0.5$ each at 30 and 45 DAS $\left(\mathrm{T}_{8}\right)$ showed the higher Fe content (4.781 $\mathrm{mg} \mathrm{kg}^{-1}$ ) as compared to their individual spray while, the increase in $\mathrm{Fe}$ content in these treatments was 33.69 per cent over control. The findings are in conformity with Radhika et al., (2013).

Among the soil application of $\mathrm{Fe}$ and $\mathrm{Zn}$ treatments, the maximum zinc content $(1.015$ $\mathrm{mg} \mathrm{kg}{ }^{-1}$ ) while, the increase in $\mathrm{Zn}$ content due to these treatments was 65.30 percent was noted under RDF $+25 \mathrm{~kg} \mathrm{ha}^{-1} \mathrm{FeSO}_{4}+25 \mathrm{~kg}$ $\mathrm{ha}^{-1} \mathrm{ZnSO}_{4}\left(\mathrm{~T}_{5}\right)$ followed by the treatment $\mathrm{T}_{4}$ i.e. $\mathrm{RDF}+25 \mathrm{~kg} \mathrm{ha}^{-1} \mathrm{ZnSO}_{4}\left(0.872 \mathrm{mg} \mathrm{kg}^{-1}\right)$ and both the treatments were found at par. However, among foliar application, RDF + foliar spray of $\mathrm{ZnSO}_{4} @ 0.5 \%$ at 30 \& 45 DAS $\left(\mathrm{T}_{7}\right)$ recorded the higher $\mathrm{Zn}$ content of $0.697 \mathrm{mg} \mathrm{kg}^{-1}$. Similar line of results was reported earlier by Ghritlahare et al., (2015).

Soil and foliar application of $\mathrm{Fe}$ and $\mathrm{Zn}$ along with RDF found beneficial in improving the soil nutrient status, nutrient uptake and there by pearl millet yield.

\section{References}

Anonymous, (2019) Economic survey of Maharashtra Directorate of economical statistics, Department of planning government of Maharashtra, Mumbai.

Asha, L., Chidanandappa, H. M., Veeranagappa, P., and Punithraj, T.S.,2012. Effect of different methods of zinc application on growth and yield of maize (Zea mays L.). Asian Journal of Soil Science, 7(2): 253-256.

Ravi, S. and Channal, H. T., 2010. Effect of sulphur, zinc and iron nutrition on growth, yield, nutrient uptake by 
safflower (Carthamus tinctorius L.). Asian Journal of Soil Science, 5 (1): 178-181.

Durgude, A. G., Kadam, S. R., and Pharande, A. L.,2014. Effect of soil and foliar application of ferrous sulphate and zinc sulphate on nutrient availability in soil and yield of Bt Cotton. Asian Journal of Soil Science, 9(1): 82-86.

El-Fouly, M. M., Abou, El-Nour, E. A. A., Shaaban, S. H. A. and Zeidan, M. S. 2012. Effect of different levels of NPK and micronutrients fertilization on yield and nutrient uptake of maize plants. Journal of American Science, 8 (8), 209-214.

Ghritlahare A., Marsonia, P. J., and Sakarvadia, H. L. 2015. Effect of zinc and iron on yield and yield attributes of okra (Abelmoschus esculentus L.). Asian Journal of Soil Science, 10(1): 104-107.

Goli, M. B., Pandey, M., Bellaloui, N., and Wrachien, D. D. 2015.Effects of soil application of micro-nutrients and chelating agent citric acid on mineral nutrients in soybean seeds. Journal of Agricultural Sciences, 6, 1404-1411.

Kanzaria, K. K., Sutaria, G. S., Akbari, K. N., Vora, V. D. and Padmani, D. R. 2010. Effect of integrated nutrient management on productivity of pearl millet and soil fertility of sandy loam soils under rain fed conditions. Asian Journal of Soil Science, 5 (1): 154-156.

Kinra K. L., Nijhwan H. L. and Rao S. B (1967). Foliar versus soil application of nitrogen on pearl millet. Indian Agricultural Research Institute, Regional Station, Kanpur.

Kumar, A., Kumar, S., Kumar, P. and Kumar, P. 2014. Effect of zinc and iron application on yield and acquisition of nutrient on mustard crop (Brassica juncea L.). Journal of Plant Development Sciences, 6 (3): 413-416.
Mahatma, N., 2007. Effect of sulphur and micronutrients (iron and zinc) on yield and quality of cotton in vertisol. M.Sc. (Agri.) thesis submitted to Dharwad Agricultural University, Karnataka.

Narimani, H., Rahimi, M. M., Ahmadikhah, A. and Vaezi, B. 2010. Study on effects of foliar spray of micronutrient on yield and yield components of durum wheat. Journal of Scholars Research Library, 2 (6): 168-176.

Palta, J. A., Nandwal, A. S., Kumari, S. and Turner, N. C. (2005). Foliar nitrogen applications increase the seed yield and protein content in chickpea subject to terminal drought. Aus. J. Agric. Res. 56: 105-112.

Prasad, S.K., Singh, M.K. and Singh, R. 2014. Effect of Nitrogen and Zinc fertilizer on pearl millet under agri-horti system of eastern Uttar Pradesh. The Bioscan, 9(1): 163-166.

Radhika, K., Hemalatha, S., Maragatham and Praveen akathrine, S. 2013. Effect of foliar application of micronutrients on the yield components of rice and soil available micronutrients status. Asian Journal of Soil Science, 8 (2): 419-421.

Ravi, S. and Channal, H. T., 2010. Effect of sulphur, zinc and iron nutrition on growth, yield, nutrient uptake by safflower (Carthamus tinctorius L.). Asian Journal of Soil Science, 5 (1): 178-181.

Reddy, M., Padmaja, B., Malathi, S. and Rao, J., 2007.Effects of micronutrients on growth and yield of pigeon pea. Journal of Agricultural Research (ICRISAT),5(1):1-3.

Sangh, R., Halepyati, A. S., Pujari, B. T., Koppalakar, B. G. and Narayanarao, K., 2012.Effect of macro and soluble micronutrients on yield, uptake of nutrients, quality and economics of $\mathrm{Bt}$ cotton (Gossypium hirsutum L.) under irrigation. Karnataka Journal of 
Agricultural Science, 25 (4): (418422).

Singh, M. V.2006. Micronutrient and secondary nutrient and Pollutant elements research in India. Coordinator report of AICRP micronutrient and secondary nutrient and pollutant elements in soil and plants. IISS, Bhopal. 30:110.

Tiwari, K. N. and Dwivedi, B. S. (1993). Fertilizer zinc demands of corn as influenced by native zinc supply in Udic Ustochrepts of Uttar Pradesh. $J$. Indian Soc. Soil Sci., 41 (4): 793-796.

\section{How to cite this article:}

Waikar, S. L., S. M. Todmal and Shete, V. S. 2021. Response of Iron and Zinc on Yield, Quality and Soil Nutrient Dynamics of Pearl Millet on Vertisol. Int.J.Curr.Microbiol.App.Sci. 10(04): 307-315. doi: https://doi.org/10.20546/ijcmas.2021.1004.032 